\title{
The Use Of Computer Mediated Communication In Consumer Complaining: A Study In Higher Education
}

Mary Beth Pinto, (Email: mxp49@psu.edu), Penn State, Erie Phylis Mansfield, (Email: pmm16@psu.edu), Penn State, Erie

\begin{abstract}
The electronic channel for consumer complaining has increased dramatically in recent years and continued growth is expected in the future. The objective of this research was to explore how computer-mediated communication is being used as a channel for complaining in higher education. A study was conducted of the complaint intentions of 222 students at one college in the eastern half of the United States. Four complaining dimensions were studied: Voice, Negative Word-of-Mouth, Third Party, and Exit. The results indicated that the most common behavioral intentions are: Complain to other students face-to-face, complain to the professor in office, and never take another class from the professor. The research findings also indicate the number of students who are likely to use computer-mediated communication to complain. In addition, the results show strong correlations between computer-mediated complaining and other complaining responses.
\end{abstract}

\section{INTRODUCTION}

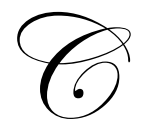

ompetition and budget constraints have encouraged colleges and universities to look for new ways to attract and keep students. Relying on models from business and marketing, many academic institutions have begun to view students as customers and themselves as service providers (Lenington, 1996; Browne, Kaldenberg, Browne, and Brown 1998; McCollough and Gremler, 1999). According to this perspective, university education is seen as a financial investment and students are equated with customers shopping for the best value for their money (Kemp, 1998). Although there is a great deal of controversy surrounding the student vs. customer debate (Salisbury, Branson, Altreche, Funk, and Broetzmann,1997; Scrabec, 2000; Grayson, 2005; Shelley, 2005), higher education administrators nonetheless remain interested in issues of student (customer) satisfaction, dissatisfaction, and complaining behavior.

Within the field of consumer behavior, researchers have addressed the impact that customer satisfaction and customer complaining behavior have on an organization's success. Improving customer satisfaction has been shown to improve customer retention rates, increase market share and profitability, and decrease negative word-of-mouth communication (Stauss and Seidel, 2004; Reichheld, 1994, 2001; Rust and Zahorik 1993; Rust, Zahorik and Keiningham, 1995). It is commonly accepted that it is more cost effective to keep an existing customer than it is to acquire a new one. Organizations have realized that consumer complaints are opportunities to resolve problems and enhance their relationship with the consumer, who has been found to be more loyal than if no complaint was ever made (Stauss and Seidel, 2004). Marketers develop complaint management techniques to satisfactorily resolve complaints and turn dissatisfied consumers into satisfied ones, positively impacting repurchase and retention rates (Bearden and Oliver, 1985; Halstead and Page, 1992).

Research on consumer complaining suggests that consumers do not simply engage in a single specific behavior such as complain or not complain. Rather, the responses of dissatisfied consumers have been categorized into several different models of complaining behavior (Hirschman, 1970, Day and Landon, 1977; Singh, 1988, 1989, 1990). Regardless of the specific classifications used, the models generally include the following behaviors: 1) Voice: defined as direct complaining to the organization; 2) Negative Word-of-Mouth (i.e. talk to family, friends, or co- 
workers); 3) Third party: which are complaints to an external entity such as the Better Business Bureau or the media; and 4) Exit: where there is no complaining involved but customers shift patronage and/or stop using the dissatisfying product or service. Most consumers carry out more than one of these behaviors when they have a bad experience such as talking to friends and relatives and also complaining to the organization (Singh and Pandya, 1991; Day, 1984; Richins, 1983).

The manner in which dissatisfied customers manifest their complaints has an impact on the organization. When customers manifest their dissatisfaction through "voice" behavior, the organization is aware of the issue and has an opportunity to rectify the situation and satisfy the satisfied customer. However, if customers engage in negative word-of-mouth, third party, or exit behaviors, the organization is unaware of the issue (at least at the present time) and has no opportunity to make restitution to the current customer or to rectify the problem for future customers. Empirical research on complaint behavior shows that "unvoiced complaints vary depending on the product segment and the type of problem, but it more than 50 percent of dissatisfied customers do not complain" (Stauss and Seidel, 2004, p. 36). Organizations should be interested in the manner in which their customers respond when dissatisfied and attempt to move them toward the "voice" behavior.

A new technological advancement in consumer complaint behavior that is in the early stages of consideration is the use of computer-mediated communication such as the internet or email. The electronic complaint channel has increased dramatically in recent years and continued growth is expected in the future (Stauss and Seidel, 2004). Computer mediated communication is particularly important among college-age students. The use of the internet, email, and instant messaging has become ubiquitous on college campuses today (Romeo, 2004). Computer mediated communication allows students today to be continuously connected to other students, faculty, family, and friends in ways that older generations were not (Irvine, 2004; Hoffman, Novak, and Venatesh, 2004). All "official and unofficial communication" between instructors and students on campuses today occurs via computer mediated communication (McHardy, 2004, p. 4). A study conducted by Harris Interactive reveals that "90 percent of American college students own their own computers and 65 percent have access to broadband Internet connections" (Roach, 2004, p. 37). According to Aiken, Banjani, Ray, and Martin (2003), about 93 percent of American college students access the Internet in a given month and the number of student users is expected to reach 16.4 million in 2007. They report college students spend on average 24.7 hours per month on the internet with 7.3 hours per month for campus email specifically (p. 183).

The proliferation of computer mediated communication on college campuses suggests the need to reconsider complaining responses within the context of higher education. The existing scales for measuring consumer complaining behavior must be broadened to include the electronic complaint channel. For example, when students want to complain directly to an instructor they have an option of complaining in class, in his/her office, or via email. For third party complaining, students now have the option of posting negative comments on an electronic bulletin board (i.e. www.ratemyprofessor.com). Negative word-of-mouth can be spread face-to-face or now via email. This paper explores how computer mediated communication is being used as a channel for student complaining behaviors. The following research questions will be addressed:

1) What are the complaint behaviors of students?

2) How likely will students use computer mediated communication to complain?

3) Is greater internet usage (i.e. more hours logged onto the internet/email) associated with more computermediated complaint responses?

4) Is there a relationship between computer-mediated complaint behavior and other complaining responses?

\section{METHOD}

\section{Sample}

Emails were sent to a convenience sample of undergraduates who attended a public university in the eastern half of the United States during the 2004-2005 academic year. The institution chose a sample of students that represented fifty percent of the undergraduate student body and distributed an email to them that contained a link to 
the survey. The researchers did not have access to the email addresses. The recipients of the emails were invited to participate in a study on complaining behavior in a college setting. A link to a survey hosting service, Zoomerang, was included in the email. A total of 1,450 emails were sent to undergraduates and 304 completed surveys were received through the hosting service (21\% response rate). This sample was further reduced to a sample size of 260 by listwise deletion of missing values. Data were collected in strict adherence to the school's policy on human subject research.

Given the purpose of the study, the sample was reduced to include only students less than 24 years of age. This is the age group most commonly known as traditional college students (Justice and Dornan, 2001) Respondents who were 24 or older were considered non-traditional students and were eliminated from our sample, for a final sample size of 222. The average age was 19.3 years, with a standard deviation of 1.2 years. The respondents were $68 \%$ female, over $97 \%$ single, and $87 \%$ white. The class breakdown was: $41 \%$ (first year students), $32 \%$ (second year students); $12 \%$ (third year students); and 13\% (fourth year students.

\section{Measures}

\section{Complaint Intentions}

Following the methodology of Singh (1989) and Slama \& Williams (1991), respondents were presented with a case scenario for collecting data on student complaining behavior. The situation selected for this scenario was one with which students should easily identify - specifically, an instructor refusing to accept a late paper due to a printer's malfunction. The scenario was developed based on two focus groups with a total of 6 faculty members. Focus groups participants were chosen from the School of Business at a public college in the eastern half of the United States. While the results of focus groups are not quantifiable, we relied on this methodology for purely exploratory purposes to provide us with a better understanding of common situations in which undergraduates are dissatisfied and likely to complain to their professors. (See Appendix for a description of the scenario).

Respondents were asked to indicate how likely they would be to carry out specific complaint responses. Items were coded on a 5 point Likert scale, anchored by $1=$ Very Unlikely and $5=$ Very Likely. A modified version of Singh (1989) Intensions construct (INTEN) was utilized. Consistent with the complaining behavior literature (Singh and Pandya, 1991), the scale included items for each of the four complaining dimensions: Voice, Negative Word-of-Mouth, Third Party and Exit. Items regarding computer-mediated communication were included in Voice, Negative Word-of-Mouth, and Third Party responses.

We then conducted reliability tests on the scales for each complaining behavior dimension. The Voice construct was measured by three items: complain to professor in class, complain to professor in his/her office, and complain to professor via email $(\alpha=.77)$. The Negative Word-of-Mouth construct included 2 items: complain to other students face-to-face, complain to other students via email $(\alpha=.67)$. The Third Party construct was measured with three items: talk to an administrator, talk to student government representative, and post a negative comment to an online chat room $(\alpha=.72)$. Exit was measured with a single item: never take another course from that professor. While one of the dimensions (negative word-of-mouth) has an alpha lower than the normally accepted standard of .70 (Nunnally, 1978), Carmines and Zeller (1979) suggest that in the development of new constructs in exploratory analysis, we may apply more relaxed standards.

Internet Usage

Respondents were asked to indicate the number of hours per week they spent logged onto the Internet/email.

\section{RESULTS AND DISCUSSION}

To answer the first two research questions we analyzed the complaint behavior of students. The means and standard deviations for each behavioral intention are included in Table 1. The table shows that the most common behavioral intentions are: Complain to other students face-to-face $(\mathrm{x}=2.89)$, Complain to professor in office $(\mathrm{x}=$ 
2.67), and Never take another course from the professor $(x=2.66)$. The fact that complaining to other students faceto-face has the highest mean is supported by Carner and Gunter (2001) who claim that out of all the complaint options, most customers will complain to their friends. Overall, the means appear to be quite low suggesting a relatively low likelihood of carrying out any of the complaint responses. The low numbers may be a result of the defensive mechanisms instituted by many colleges and universities that make complaints expensive (in terms of psychological and social risk), difficult, and uncomfortable for students (Fornell 1978). For example, a student may be hesitant to complain to a professor they will have in other classes or need for a recommendation to graduate school or a potential employer.

Table 1 also shows the number and percentage of students that intend to carry out a complaining response. Readers will note that the sum of the frequencies in these categories do not add up to one hundred percent because students were asked to indicate their likelihood of employing each of the complaint options. For example within the Voice category, only $10.4 \%$ of the sample indicated they would likely complain in class to their professor; however, $33.3 \%$ of the students indicated a willingness to complain to the professor privately in his or her office. In the category of Third Party complaining, the behavioral intention frequencies were considerably lower overall than any of the other complaining options. One possible explanation for this finding is the nature of the case scenario used in this study. Stauss and Seidel (2004) note that complaining behavior and outlets selected to complain are based on situational attributes. Respondents' may have reported different behavioral intentions regarding another scenario (e.g., depending on the degree of costs versus benefits of complaining). "Consumers use a cost/benefit approach to complaining; those with more at stake take more assertive actions and spend more time pursuing their complaint" (Hogarth, Hilgert, Kolodinsky, and Lee, 2001, p. 88).

Table 1: Complaining Behavior Of Dissatisfied Students $\mathrm{N}=222$

\begin{tabular}{|l|c|c|c|c|}
\hline \multicolumn{2}{|l|}{ Case Scenario } & \multicolumn{2}{l|}{ Std. Deviation } \\
\hline Complaining Behavior & Mean $^{*}$ & Frequency $^{* *}$ & Percent & 1.12 \\
\hline Complain to the professor in class & 1.95 & 23 & $10.4 \%$ & 1.48 \\
\hline Complain to the professor in his/her office & 2.67 & 73 & $33.3 \%$ & 1.39 \\
\hline Complain to the professor via email & 2.42 & 57 & $26.8 \%$ & 1.16 \\
\hline Complain to other students via email & 1.86 & 28 & $12.8 \%$ & 1.45 \\
\hline Complain to other students face-to-face & 2.89 & 81 & $37.7 \%$ & 1.24 \\
\hline Talk to an administrator & 1.96 & 33 & $15 \%$ & .84 \\
\hline Talk to a student governance representative & 1.50 & 7 & $3.2 \%$ & .93 \\
\hline Post a negative comment to an on-line chat room & 1.46 & 13 & $6.0 \%$ & 1.45 \\
\hline Never take another course from that professor & 2.66 & 78 & $31 \%$ & \\
\hline
\end{tabular}

"Scale: 5 point Likert scale, anchored by $1=$ Very Unlikely and $5=$ Very Likely

${ }^{* *}$ Frequency: \# of responses of 4 or 5 on the 5 -point Likert Scale

In terms of exit behavior, over 30\% of students indicated that they would never take another course from that professor. This type of response is supported by empirical research that shows a majority of dissatisfied customers do not complain. According to Stauss and Seidel (2004), "the percentages of unvoiced complaints vary depending on the product segment and the type of problem" (p.36). Finally, it is also interesting to note that the most common complaint intentions fall into multiple complaint categories, specifically voice, negative word-of-mouth, and exit. These results are consistent with Singh and Pandya (1991) who found that "people often engage in multiple complaint processes (e.g. voice and negative word-of-mouth)" (p.11).

The second research question asks, "How likely will students use computer mediated communication to complain?" Table 1 demonstrates that $26.8 \%$ of students would likely complain to their professor via email, $12.8 \%$ would complain to other students via email, and $6 \%$ would likely post a negative comment to an online chat room. It is interesting to note more students would be likely to complain to their professor via email than to complain in class. One explanation for this result is that when a message is sent electronically, it is not interpersonally confrontational and the senders do not "expose themselves to a direct, critical conversation" (Stauss and Seidel 2004, p.43). Senders 
also experience less psychological and social risk (i.e., embarrassment and public sanctions) because the interaction occurs privately (Inks and Mansfield, 1996).

One anticipated reason why technology might encourage students to complain more frequently is that technology makes complaining easier. Snellman and Vihtkari (2003), however, found no difference in the perceived easiness of complaining between computer-mediated complaining and via traditional channels. In their study of a Finnish retail banking firm, of the 52 respondents who complained, only six people wrote an email. Email was only used in one fifth of the cases. The most frequent channel of complaining was a voice responses while in the bank.

In terms of internet usage, the students reported being logged onto the internet or email for an average of 10.29 hours per week, with a range of 1 to 65 hours per week. To answer the third research question, "Is there a relationship between internet usage and computer mediated complaint responses," we conducted Pearson ProductMoment correlations. Our findings showed only one significant correlation between hours spent logged onto the internet/email and computer mediated complaint behavior. This result was not expected given the degree that college students make use of the internet today for recreational uses and academic purposes (Aiken, Vanjani, Ray, and Martin 2003). Internet usage was significantly correlated with posting negative comments to online chat sites. Surprisingly, these two items were negatively correlated suggesting that more internet usage is associated with less negative posting to these types of chat sites. One explanation for these findings may be that complaining behavior is not a function of internet usage but rather more a function of other factors such as expectations for resolution, personality types, and age.

The final research question asked, "Is there relationship between computer-mediated complaining and other complaining responses?" The results show strong correlations between all complaining behaviors dimensions. In fact, the correlation matrix (see Table 2) showed strong inter-correlations among all complaining behaviors, further supporting the fact that complainers often engage in multiple complaining behaviors. These results suggest that complaining behavior may be impacted less by the medium than by other factors, such as personality issues. Previous studies have found that complainers tend to have more aggressive personalities than non-complainers (Richins 1983).

\section{MANAGERIAL IMPLICATIONS}

Internet usage is a mainstay of our society today and it is well accepted that the "most Internet-connected demographic group is college students" (Aiken, Vanjani,Ray, and Martin 2003, p. 183). Since it is more commonplace today to consider students as customers of higher education, administrators must consider the role of computer-mediated communication in the process of maintaining customer satisfaction. Research on consumer complaining behavior suggests that it is more preferable to the marketer if dissatisfied customers use "voice" behaviors, manifesting their complaints immediately and directly, so that the marketer has an opportunity to rectify the situation and enhance the relationship with the customer. In the case of higher education services, voice behaviors can now occur in the classroom, in a faculty office, or via email. Managers of higher education should encourage professors to establish some type of formal complaint process through voice actions at the beginning of each course. For example, professors could set up regularly scheduled meetings with students in their offices so that the students could offer feedback on their perceptions of any unfair or dissatisfying experiences. Another method of voicing complaints could be for professors to utilize one of the electronic course management systems where students could post their dissatisfaction on-line, directly to the professor.

The most undesirable behavior from the marketer's perspective would be for the customer to "exit" the relationship, never buying from that marketer again. In this study of complaining behavior in higher education, the behavior of "exit" refers to not taking a course from a specific professor again, rather than exiting the relationship with the university itself. Should a student have multiple negative experiences, or if these occur during the first year of study, he/she might become dissatisfied with his/her university experience or experience within a particular major and choose to change majors or leave the relationship and transfer to another institution. This decision can have significant implications for retention rates, therefore, administrators should encourage the Voice complaint procedures outlined above to minimize retention loss. Additional research would be required to determine the effect that a single dissatisfactory incident has on the overall evaluation of the university experience. 
Table 2: Correlation Matrix

\begin{tabular}{|c|c|c|c|c|c|c|c|c|c|c|}
\hline & 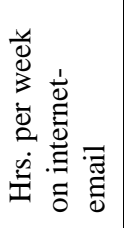 & 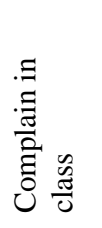 & 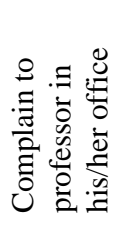 & 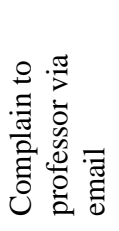 & 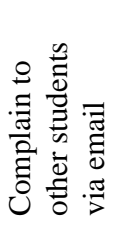 & 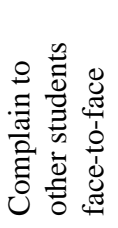 & 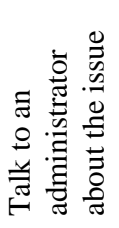 & 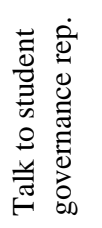 & 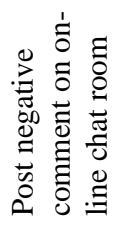 & 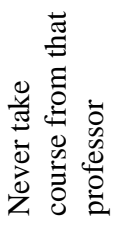 \\
\hline \multicolumn{11}{|l|}{$\begin{array}{l}\text { Hrs. per week on } \\
\text { internet-email }\end{array}$} \\
\hline Complain in class & -.01 & & & & & & & & & \\
\hline $\begin{array}{l}\text { Complain to } \\
\text { professor in his/her } \\
\text { office }\end{array}$ & .00 & $.45^{* *}$ & & & & & & & & \\
\hline $\begin{array}{l}\text { Complain to } \\
\text { professor via email }\end{array}$ & .08 & $.46^{* *}$ & $.67 * *$ & & & & & & & \\
\hline $\begin{array}{l}\text { Complain to other } \\
\text { students via email }\end{array}$ & -.05 & $.40 * *$ & $.28 * *$ & $.40 * *$ & & & & & & \\
\hline $\begin{array}{l}\text { Complain to other } \\
\text { students face-to-face }\end{array}$ & .08 & $.39 * *$ & $.35 * *$ & $.38 * *$ & $.52 * *$ & & & & & \\
\hline $\begin{array}{l}\text { Talk to an } \\
\text { administrator about } \\
\text { the issue }\end{array}$ & -.05 & $.39 * *$ & $.57 * *$ & $.50 * *$ & $.40 * *$ & $.28 * *$ & & & & \\
\hline $\begin{array}{l}\text { Talk to student } \\
\text { governance rep. }\end{array}$ & -.12 & $.28 * *$ & $.31 * *$ & $.32 * *$ & $.39 * *$ & $.14^{*}$ & $.62 * *$ & & & \\
\hline $\begin{array}{l}\text { Post negative } \\
\text { comment on on-line } \\
\text { chat room }\end{array}$ & $-.15^{*}$ & $.27 * *$ & $.16^{*}$ & $.22 * *$ & $.50 * *$ & $.23 * *$ & $.31 * *$ & $.55^{* *}$ & & \\
\hline $\begin{array}{l}\text { Never take course } \\
\text { from that professor }\end{array}$ & -.01 & $.41 * *$ & $.34 * *$ & $.36 * *$ & $.31 * *$ & $.51 * *$ & $.33 * *$ & $.21 * *$ & $.34 * *$ & \\
\hline
\end{tabular}

$$
\begin{aligned}
& \mathrm{p}<.001=* * \\
& \mathrm{p}<.05=*
\end{aligned}
$$

\section{LIMITATIONS AND FUTURE RESEARCH}

Complaining behavior is a contingent phenomenon; i.e., the attributes of the product, problem, person, and situation, as well as potential benefits and costs, all weigh in the decision of whether or not to complain. This study created a single case scenario as a point of reference for measuring complaint intentions. While some students could relate to this scenario, others perhaps, could not (what is important to one student may not be as important to another). As a result, the generalizability of our findings may be limited to only this specific situational scenario. Though a point of valid concern, we followed a common methodology used by a number of researchers in the complaining literature (Singh, 1989; Slama \& Williams, 1991). Future research may want to consider other situational factors that impact complaining behavior in higher education.

A second limitation is the sample population. As we described in the methodology section, this study was conducted at a single university. Given that complaining behavior varies widely over situations, products/services, and individuals, future research should broaden the population to include multiple segments from different geographical regions, age categories, and socioeconomic classes. Inviting respondents to participate in our study via 
email may have biased our respondents to be heavier Internet users. The methodology utilized in this study may have impacted our sample size. We believe it also lowered our response rate because students may have just deleted the email thinking that it was one of the many pieces of junk or spam mail that they receive on a daily basis.

Finally, future research should investigate the impact of student involvement on intention to complain. The marketing literature suggests that involvement in a product category influences behavioral intent (Richins \& Verhage, 1985). Thus, if a student perceives that damage could be substantial as a result of a professor's action (i.e., failing a course in your major), he/she may be more likely to complain or seek redress than in a course having lower involvement (i.e., a general education elective). Future research should test the impact of importance on complaining behavior.

\section{APPENDIX - SCENARIO}

In one of your classes, your professor collected an assignment that was due today. Unfortunately, you did not have the assignment ready to turn in because your computer malfunctioned last night and you could not print the assignment. Even though the course syllabus states that "late assignments will not be accepted," you decided to request an extension on the assignment until the next day. When you told your professor about the malfunction, he/she said, "This is unfortunate for you" and would not honor your request.

\section{REFERENCES}

1. Aiken, M., Vanjani M., Ray B., and Martin J. (2003) College Student Internet Use, Campus-Wide Information Systems, Vol. 20, No. 5, pp. 182-185.

2. Bearden, W. O. and Oliver, R. L. (1985) The Role of Public and Private Complaining in Satisfaction with Complaint Resolution, Journal of Consumer Affairs, Vol. 19, No. 2, pp. 222-240.

3. Browne, B. A., Kaldenberg, D. O., Browne, W. B., and Brown, D. (1998) Student as Customer: Factors Affecting Satisfaction and Assessments of Institutional Quality, Journal of Marketing For Higher Education, Vol. 8, No. 3, pp. 1-14.

4. Carder, S. and Gunter L. (2001) Customer Satisfaction, Customer Feedback, Complaints, and Communication, Journal of American \& Comparative Cultures, Vol. 24, No. 3/4, pp. 109-113.

5. Carmines, E. G. and Zeller, R. A. (1979), Reliability and validity assessment, Sage, Beverly Hills, CA.

6. Day, R. L. and Landon, E. L. Jr. (1977) Toward a Theory of Consumer Complaining Behavior, in Woodside A. G., Sheth, J., and Bennett P. (Eds.), Consumer and Industrial Buying Behavior, Elsevier North-Holland, Inc., pp. 425-437.

7. Day, R. L. (1984) Modeling Choices Among Alternative Responses to Dissatisfaction. in Kinnear, T. (Ed.), Advances in Consumer Research, Association of Consumer Research, Ann Arbor, MI, Vol. 11, pp. 496-499.

8. Grayson, K. (2005), Who's a Customer? University Business. Available (University Business FEBRUARY) http://www.universitybusiness.com/pageprint.cfm?p=320

9. Halstead, D. and Page, T. J. Jr. (1992) The Effects of Satisfaction and Complaining Behavior on Consumer Repurchase Intentions, Journal of Consumer Satisfaction, Dissatisfaction, and Complaining Behavior, No. 5, pp. 1-11.

10. Hirschman, A. O. (1970), Exit, Voice, and Loyalty: Responses to Decline in Firms, Organizations, and States, Harvard University Press, Cambridge.

11. Hoffman, D. L., Novak, T. P., and Venkatesh, A. (2004) Has the Internet Become Indispensable?, Communications of the ACM, Vol. 47, No.7, pp. 37-42.

12. Hogarth, J. M., Hilgert, M. A., Kolodinsky, J. M., and Lee, J. (2001) Problems with credit cards: An Exploration of consumer complaining behaviors, Journal of Consumer Satisfaction, Dissatisfaction, and Complaining Behavior, Vol. 14, pp. 88-107.

13. Irvine, M. (2004) In Continuous Communication/Internet Shapes how a generation lives, works, relaxes, and expresses itself, Houston Chronicle, December 5, pp. 5.

14. Justice, E. M. and. Dornan, T. M. (2001) Metacognitive Differences Between Traditional-Age and Nontraditional-Age College Students, Adult Education Quarterly, Vol. 5, No. 3, pp. 235-249. 
15. Kowalski, R. B. (1996) Complaints and complaining: Functions, antecedents, and consequences, Psychological Bulletin, Vol. 119, pp. 179-196.

16. Lenington, R. L. (1996), Managing Higher Education as a Business, Oryx Press, Phoenix.

17. McHardy, A. (2004) Clearing 2004: When technology does the talking: With email now the most common form of communication used between students and lecturers in many colleges and universities, The Guardian, August 24, pp.4.

18. McCollough, M. A. and. Gremler, D. D (1999) Guaranteeing Student Satisfaction: An Exercise in Treating Students as Customers, Journal of Marketing Education, Vol. 21, pp. 118-130.

19. Nunnally, J. C. (1978). Psychometric theory, McGraw-Hill, New York.

20. Reichheld, F. (1994) Loyalty and the Renaissance of Marketing, Marketing Management, Vol. 2, No.4, pp. 15.

21. Reichheld, F. (2001), Loyalty Rules!, Harvard Business School Press, Boston.

22. Richins M. L. (1983) Negative Word-of-Mouth by Dissatisfied Consumers: A Pilot Study, Journal of Marketing, Vol. 47, No. 1, pp. 68-78.

23. Richins, M.L. and Verhage, B. J. (1985) Seeking Redress for Consumer Dissatisfaction: The Role of Attitudes and Situational Factors, Journal of Consumer Policy, 8(1), 29-45.

24. Romeo, J. (2004) The Well-Wired (or Wireless) Campus, The Hispanic Outlook in Higher Education, Vol. 14, No. 21, pp. 25.

25. Rust, R. T. and Zahorik, A. J. (1993) Customer Satisfaction, Consumer Retention and Market Share, Journal of Retailing, Vol. 69, No. 2, pp. 193-215.

26. Rust, R. T., Zahorik, A. J., and Keiningham, T. L. (1995) Return on Quality (ROQ: Making Service Quality Financially Accountable, Journal of Marketing, Vol. 59, No. 2, pp. 58-70.

27. Salisbury, D. F., Branson, R.K., Altreche, W. I., Funk, F. F., and Broetzmann, S. M. (1997) Applying Customer Dissatisfaction Measures to Schools: You Better Know What's Wrong Before You Try to Fix It, Educational Policy, Vol. 11, pp. 286-308.

28. Scrabec, Q., Jr. (2000) A Quality Education Is Not Customer Driven, Journal of Education for Business, Vol. 75, No. 5, pp. 298-300.

29. Shelley, P. H. (2005) Colleges Need to Give Students Intensive Care, The Chronicle of Higher Education, Vol. 51, No. 18, p. B16.

30. Singh, J. (1988) Consumer Complaint Intentions and Behavior: Definitional and Taxonomical Issues, Journal of Marketing, Vol. 52, pp. 93-107.

31. Singh, J. (1989) Determinants of consumers' Decisions to Seek Third Party Redress: An Empirical Study of Dissatisfied Patients, Journal of Consumer Affairs, Vo. 23, No. 2, pp. 329-363.

32. Singh, J. (1990) A Typology of consumer Dissatisfaction Response Styles, Journal of Retailing, Vol. 66, No. 1 , pp. 57-99.

33. Singh, J. and Pandya, S. (1991) Exploring the Effects of Consumers' Dissatisfaction Level on Complaint Behaviours, European Journal of Marketing, Vol. 25, No. 9, pp. 7-21.

34. Slama, M. E. and Williams, T. G. (1991) Consumer Interaction Styles and Purchase Complaint Intentions, Journal of Consumer Satisfaction, Dissatisfaction, and Complaining Behavior, Vol. 4, pp. 167-174

35. Snellman, K. and Vihtkari, T. (2003) Customer complaining behaviour in technology-based service encounters, International Journal of Service Industry Management, Vol. 14, No. 2, pp. 217-231.

36. Stauss, B. and Seidel, W. (2004), Complaint Management: The Heart of CRM, Thomson Business and Professional Publishing, Mason, $\mathrm{OH}$. 